\title{
Бачурина А.C. \\ Фактор некроза опухоли у детей после аденотонзиллэктомии и его оценка
}

Ростовский государственный медицинский университет

(Россия, Ростов-на-Дону) doi:10.18411/lj2016-4-20

Гипертрофия лимфокольца глотки является одним из распространенных заболеваний в детской оториноларингологии. Консервативное лечение часто не дает желаемого результата. Основным методом лечения в течение многих лет остается аденотонзиллотомия $[1,2]$.

Определение показаний для выполнения аденотонзиллотомии часто вызывает затруднения у клинициста [3, 4], поскольку глоточная и небная миндалины входят в состав лимфоидной ткани, ассоциированной со слизистой оболочкой верхних дыхательных путей (MALT) и являются одним из главных источников иммунных клеток. И если для аденотомии существуют четкие показания, то вопрос и необходимости частичного или полного удаления небных миндалин в детском возрасте весьма дискутабелен [5].

В развитии иммунных реакций определяющую роль играют цитокины, которые регулируют развитие и течение воспаления [6]. Многие из них присутствуют в слюне, в том числе, фактор некроза опухоли (TNF- $\alpha)$.

Целью нашего исследования были изучение динамики и оценка провоспалительного цитокина TNF- $\alpha$ в слюне у детей до и после аденотонзиллотомии.

Фактор некроза опухоли (TNF- $\alpha$ ) является одним из значимых цитокинов с широким спектром действия, значения которого меняются при различных состояниях. Существует ряд заболеваний, при которых роль TNF- $\alpha$ считается крайне важной. Нами проведено исследование TNF- $\alpha$ до и после аденотонзиллотомии.

Материалы и методы исследования. В исследовании приняли участие 10 детей в возрасте от 3 до 7 лет, перенесших плановую аденотонзиллотомию по поводу гипертрофии лифокольца глотки и 10 детей контрольной группы. У всех детей, подвергшихся оперативному вмешательству, имелись жалобы на затрудненное носовое дыхание, частые ангины, нарушение сна, вялость, утомляемость, рецидивирующие гнойные синуситы и средние отиты, часто со снижением слуха, обструктивное апное сна.

Для установления точного диагноза амбулаторно всем детям было проведено общеклиническое обследование и эндоскопический осмотр полости носа и носоглотки.

Обследуемым производили забор слюны утром, без стимуляции, накануне операции и на 1-ый, 2-ой, 3-ий, 4-ый и 5-ый дни после оперативного вмешательства, в которой исследовали TNF- $\alpha$. Каждому больному было произведено по 6 анализов. Уровень TNF- $\alpha$ определяли с помощью наборов для иммуноферментного анализа фирмы ЗАО «Вектор Бест» (Россия) методом твердофазного иммуноферментного анализа количественного определения цитокинов в слюне. Результаты исследования обрабатывали с использованием пакета стандартных компьютерных программ для статистического анализа «Statistica 7,0».

Результаты. При анализе полученных результатов распределение уровня TNF- $\alpha$ было проведено на соответствие нормальному распределению. При этом использовали закладку «Тест на нормальность» в модуле «Частотный анализ» в программе STATISTICA 7.0. При проведении теста Шапиро - Уилка в исходных показателях основной группы и контрольной подтверждена гипотеза об имеющихся отличиях распределения показателя уровня TNF- $\alpha$ от нормального с доверительной вероятностью менее 0,03 .

Достоверность различий исходных величин зависимых выборок (то есть внутри группы) оценивали с помощью непараметрического критерия Уилкоксона. Статистический анализ динамики исследуемого показателя внутри группы выявил достоверное увеличение TNF- $\alpha$ после операции на 1ый, 2-ой и 3-ий дни, а в последующие дни (4-ый, 5-ый) - незначительное его уменьшение $(\mathrm{p} \leq 0,05)$. 
При сравнении исходных величин независимых выборок основной и контрольной групп между собой использовался критерий Манна-Уитни, при этом достоверных различий между показателями не выявлено $(\mathrm{p}>0,05)$.

\section{Выводы:}

1. Исходный уровень TNF- $\alpha$ в слюне у детей с гипертрофией лимфокольца глотки не отличается от показателей контрольной группы.

2. Уровень TNF- $\alpha$ после аденотонзиллотомии достоверно возрастает в первые 3 дня после операции, а в последующие дни (4-ый, 5-ый) незначительно снижается.

\section{Список используемых источников информации}

1. Бойко Н.В., Бачурина А.С. Аденотомия и аденотонзиллотомия у детей с затруднением носового дыхания. Рос. ринология. 2015. Т. 23. № 1. С. 9-12.

2. Бойко Н.В., Гукасян Е.Л., Быкова В.В. Статистика хирургических вмешательств при хроническом тонзиллите. Вестник оториноларингологии. 2008. № 5. С. 234.

3. Бойко Н.В., Бачурина А.С., Жданов А.И. Профилактика послеоперационных кровотечений при аденотомии. Рос. ринология. 2015. Т.23. № 2. С.26-30.

4. Власова Т.М., Бойко Н.В. Рост числа постстрептококковых осложнений у больных хроническим тонзиллитом. Рос. оторинолар. 2015. № S1. С. 45-47.

5. Бойко Н.В., Локшина Л.С., Сорока Г.Г., Бриж Ю.В., Сулина Н.Ю. Изменение подходов к лечению хронического тонзиллита в детском возрасте по материалам Ростовской ЛОР клиники. Вестник оторинолар. 2012. № 5. С. 226.

6. Бойко Н.В., Бачурина А.С., Оксенюк О.С., Колмакова Т.С. Лечение послеоперационного воспаления после тонзиллэктомии у детей. Педиатрия им. Г.Н. Сперанского. 2016. Т. 95. № 1. С. 93-97.

\section{Бачурина А.C. \\ Статистический анализ уровня IL-1 у детей до и после аденотомии}

Ростовский государственньй медицинский университет (Россия, Ростов-на-Дону) doi:10.18411/lj2016-4-21

Цитокины представляют собой группу полипептидных медиаторов, участвующих в формировании и регуляции защитных реакций организма. Они могут быть выделены в новую самостоятельную систему регуляции основных функций организма, существующую наряду с нервной и эндокринной системами регуляции и связанную в первую очередь с поддержанием гомеостаза при внедрении патогенов и нарушении целостности тканей. Защита на местном уровне развивается путем формирования типичной воспалительной реакции с ее классическими проявлениями: развитием отека, покраснением, появлением болевого синдрома и нарушением функции. Воспаление развивается в ответ на повреждение и проникновение в ткани патогенов при участии провоспалительных цитокинов, вырабатываемых макрофагами в лимфоидной ткани, включающей в себя глоточную миндалину [1].

Часто при патологии глоточной миндалины в детской оториноларингологической практике требуется хирургическое вмешательство аденотомия [2]. Абсолютными показаниями к оперативному вмешательству при аденотомии являются затруднение носового дыхания, синдром обструктивного апноэ сна, патология среднего уха, снижение слуха $[3,4,5]$.

Целью нашего исследования являлся статистический анализ уровня провоспалительного цитокина IL-1 в слюне у детей до и после аденотомии.

IL-1 относится к медиаторам ранней реакции на повреждение и связан с процессом распознавания повреждающего фактора и инициацией продукции дистатных медиаторов цитокиновой сетью. Кроме того, от цитокиновой сети, установленной IL-1, зависит экспрессия некоторых цитокинов неиммунными клетками, такими как эпителиальные и стромальные клетки, обеспечивающими репаративную роль на заключительной стадии воспаления [6, 7].

Материалы и методы исследования. Исследование проводилось на базе оториноларингологического отделения для детей ГБ№1 им. Н.А. Семашко г.Ростована-Дону. В исследовании приняли участие 37 детей в возрасте от 3 до 14 лет, 